\title{
Effects of cowpea mild mottle virus on soybean cultivars in Brazil
}

Felipe Barreto da Silva ${ }^{\text {Corresp., }}{ }^{1}$, Cristiane Muller ${ }^{2}$, Vinicius Henrique Bello ${ }^{1}$, Luís Fernando Maranho Watanabe ${ }^{1}$, Bruno Rossitto De Marchi ${ }^{1}$, Lucas Machado Fusco ${ }^{1}$, Marcos Roberto Ribeiro-Junior ${ }^{1}$, Guilherme Barbosa Minozzi ${ }^{2}$ , Lucia Madalena Vivan ${ }^{3}$, Marco Antonio Tamai ${ }^{4}$, Juliano Ricardo Farias ${ }^{5}$, Angélica Maria Nogueira ${ }^{1}$, Maria Márcia Pereira Sartori ${ }^{1}$, Renate Krause-Sakate ${ }^{\text {Corresp. } 1}$

1 Department of Plant Protection, Universidade Estadual Paulista "Julio de Mesquita Filho" (UNESP), Botucatu, São Paulo, Brazil

2 Corteva $^{\mathrm{TM}}$ Agrisciences, Mogi Mirim, São Paulo, Brazil

3 Fundação de Apoio a Pesquisa à Pesquisa Agropecuária de Mato Grosso/Fundação MT, Rondonópolis, Mato Grosso, Brazil

4 Department of Human Sciences, Universidade do Estado da Bahia/UNEB, Campus IX, Barreiras, Bahia, Brazil, Bahia, Brazil

5 Department of Entomology, Instituto Phytus, Santa Maria, Rio Grande do Sul, Brazil

Corresponding Authors: Felipe Barreto da Silva, Renate Krause-Sakate

Email address: felipe.barreto@unesp.br, renate.krause@unesp.br

Soybean stem necrosis is caused by Cowpea mild mottle virus (CPMMV), transmitted by the whitefly Bemisia tabaci. CPMMV has already been recorded in all major soybeanproducing areas of Brazil. The impacts caused by CPMMV to the current Brazilian soybean production are unknown, thus the main objective of this study was to evaluate the effects of CPMMV infection on the main important soybean cultivars grown in the Southern and Midwestern regions of Brazil. Although asymptomatic in some of the tested cultivars, CPMMV infection significantly reduced the plant height, the number of pods per plant and the 1,000-grain weight. In addition, estimated yield losses ranged from 174 to $638 \mathrm{~kg} \mathrm{ha}^{-1}$, depending on the cultivar. Evidence of seed transmission of CPMMV was observed in the BMX POTENCIA RR cultivar. These results suggest that CPMMV could have an important role in the reduction of soybean productivity in Brazil, but symptomless infections might be hiding the actual impact of this pathogen in commercial fields and infected seeds could be the primary inoculum source of the virus in the field. 
1 Effects of cowpea mild mottle virus on soybean cultivars in Brazil

2

3 Felipe Barreto da Silva1, Cristiane Muller², Vinicius Henrique Bello1, Luís Fernando 4 Maranho Watanabe ${ }^{1}$, Bruno Rossitto De Marchi ${ }^{1}$, Lucas Machado Fusco1, Marcos

5 Roberto Ribeiro-Junior ${ }^{1}$, Guilherme Barbosa Minozzi², Lúcia Madalena Vivan ${ }^{3}$, Marco

6 Antonio Tamai ${ }^{4}$, Juliano Ricardo Farias ${ }^{5}$, Angélica Maria Nogueira1, Maria Márcia Pereira

7 Sartori $^{1}$, Renate Krause-Sakate ${ }^{1 *}$

8

9

${ }^{1}$ Department of Plant Protection, Faculdade de Ciências Agronômicas, Universidade Estadual Paulista “Júlio de Mesquita Filho" (UNESP), Botucatu, São Paulo, Brazil ${ }^{2}$ Corteva ${ }^{\mathrm{TM}}$ Agrisciences, Mogi Mirim, São Paulo, Brazil

${ }^{3}$ Fundação de Apoio a Pesquisa à Pesquisa Agropecuária de Mato Grosso/Fundação MT, Rondonópolis, Brazil

${ }^{4}$ Departament of Human Sciences, Universidade do Estado da Bahia/UNEB, Campus IX, Barreiras, Bahia, Brazil

${ }^{5}$ Departament of Entomology, Instituto Phytus, Santa Maria, Rio Grande do Sul, Brazil.

\section{Corresponding Authors}

Felipe Barreto da Silva, felipe.barretods@gmail.com

Renate Krause-Sakate, renate.krause@unesp.br

Av. Universitária, 3780 - Altos do Paraiso, Department of Plant Protection, Faculdade de Ciências Agronômicas, Universidade Estadual Paulista "Júlio de Mesquita Filho" (UNESP), Botucatu, São Paulo, Brazil

\section{Abstract}

Soybean stem necrosis is caused by Cowpea mild mottle virus (CPMMV), transmitted by the whitefly Bemisia tabaci. CPMMV has already been recorded in all major soybeanproducing areas of Brazil. The impacts caused by CPMMV to the current Brazilian soybean production are unknown, so the main objective of this study was to evaluate the effects of CPMMV infection on the main important soybean cultivars grown in the 
31 Southern and Midwestern regions of Brazil. Although asymptomatic in some of the tested

32 cultivars, CPMMV infection significantly reduced the plant height, the number of pods per plant and the 1,000-grain weight. In addition, estimated yield losses ranged from 174 to $638 \mathrm{~kg} \mathrm{ha}^{-1}$, depending on the cultivar. Evidence of seed transmission of CPMMV was observed in the BMX POTENCIA RR cultivar. These results suggest that CPMMV could have an important role in the reduction of soybean productivity in Brazil, but symptomless infections might be hiding the actual impact of this pathogen in commercial fields and infected seeds could be the primary inoculum source of the virus in the field.

\section{INTRODUCTION}

Soybean [Glycine max (L.) Merril] is an important crop worldwide as a source of oilseed and protein. Brazil is the second largest producer of soybean in the world, producing 114.8 million tons in a cultivated area of 35.8 million hectares in the $2018 / 2019$ growing season. In Brazil, soybean is the most important economic crop, generating approximately 675 million US $\$$ to the internal market and 31 billion US\$ to exportation (Hirakuri \& Lazzarotto, 2014; Conab, 2018). In the last decade, the soybean cultivated area in Brazil increased $64.9 \%$, while the productivity increased from 2,800 to $3,400 \mathrm{~kg}$ ha-1 over the same time (Conab, 2018).

Soybean can be affected by several pests regardless of growth stage. The occurrence of at least 15 viral diseases have been reported in Brazil (Almeida, 2008; De Marchi et al., 2018). The Cowpea mild mottle virus (CPMMV; family Betaflexiviridae, genus Carlavirus), which is the agent of soybean "stem necrosis disease", is a single-stranded positive sense 
53 RNA virus with flexuous filamentous particles (approx. $650 \mathrm{~nm}$ in length). The genome of 548200 nucleotides, a cap structure [m7GpppG] linked to the 5' terminus and a 55 polyadenylated tail at the 3'end (Menzel, Winter \& Vetten, 2010; King et al., 2011; 56 Zanardo et al., 2014a) and has genomic organization with six open reading frames 57 (ORFs), typical of the genus Carlavirus. ORF1 encode a replicase protein containing four 58 conserved motifs: methyltransferase, C23 peptidase, RNA helicase and an RNAdependent RNA polymerase. ORF2, ORF3 and ORF4 encode proteins of the triple gene block (TGB). ORF5 encodes the coat protein (CP), and ORF6 encodes a nucleic acid binding protein (Menzel, Winter \& Vetten, 2010). CPMMV was reported infecting soybean in the 2000/2001 season in the state of Goiás, having been subsequently identified in soybean fields across Brazil in the states of Bahia, Mato Grosso, Maranhão, Paraná (Almeida et al., 2003, 2005; Almeida, 2008) and in 2008, in the Minas Gerais and Tocantins states (Almeida, 2008). Although steam necrosis is the common name of this disease, in the last years, mild mottle and mosaic were the most common symptoms observed for this virus infection (Zanardo et al. 2014; Zanardo e Carvalho 2017). The use of resistant cultivars is the most important method to reduce losses caused by virus disease. Resistant soybean cultivars to CPMMV have been reported in India (cv. F4C732 and JS335) (Cheruku et al., 2017), in Puerto Rico (cv. IA3023) (Brace, Fehr \& Graham, 2012), Indonesia (cv. MLG0120) (Suryanto et al., 2014) and in Brazil (cv. BRS 133) a former and obsolete cultivar (Arias et al., 2015; De Oliveira et al., 2018). In general, carlaviruses are transmitted by aphids (King et al., 2011), however CPMMV is one of the two exceptions of the genus that are transmitted in a non-persistent manner by the whitefly Bemisia tabaci (Gennadius) (Hemiptera: Aleyrodidae) (Almeida, 2008; 
Marubayashi, Yuki \& Wutke, 2010). This pest itself can reduce soybean productivity (Lourenção et al.,1999; Tamai et al., 2006) and was listed between the most important pest affecting this crop in Brazil (Brasil, 2019). Bemisia tabaci is also an excellent vectors of viruses (Navas-Castillo, Fiallo-Olivé \& Sánchez-Campos, 2011; Gilbertson et al., 2015), affecting several crops such as vegetables, fibres and ornamentals (De Barro et al., 2011; Lapidot et al., 2014). Bemisia tabaci is widely spread in Brazil, and the Middle East Asia Minor 1 (MEAM1, known as B biotype) is the prevalent species on major crops across the country (Moraes et al., 2018). The species Mediterranean (MED, also known as biotype Q), which was reported in the south region of our country (Barbosa et al. 2015) was recently also detected in different states of Brazil but on ornamental plants collected from flower shops (Moraes et al., 2018).

CPMMV is also easily transmitted by sap (Brunt \& Kenten, 1973), one characteristic that is very helpful to study the virus. The seed transmission of CPMMV has also been reported in different plant species such as soybean, cowpea (Vigna unguiculata) and common bean (Phaseolus vulgaris) in Africa (Brunt and Kenten 1973), yardlong bean (Vigna unguiculata subsp. sesquipedalis) in Venezuela (Brito et al., 2012), and by some soybean cultivars in India (Yadav et al., 2013). There is no information about soybean seed transmission of Brazilian CPMMV isolates (Almeida et al., 2005).

The effects caused by CPMMV to Brazilian soybean production have never been estimated (Zanardo and Carvalho 2017), and the ability of Brazilian CPMMV to be transmitted by seed is still unknown. Thus, the goal of this study was to evaluate the damage of CPMMV on the major soybean varieties used in the main growing areas of the 
98

101

102

103

104

105

106

107

108

109

110

111

112

113

114

115

116

117

118

119

Southern and Midwestern regions of Brazil. Additionally, the seed transmission ability of one CPMMV isolate from the São Paulo State was assessed.

\section{MATERIALS \& METHODS}

Obtaining CPMMV isolate, complete genome characterisation and Bayesian phylogenetic analysis

The CPMMV isolate was collected from soybeans in Casa Branca County, São Paulo State, Brazil (2016/2017). Total RNA was extracted from the leaf tissue of symptomatic soybean plants using the PureLink Viral RNA/DNA Mini Kit (Thermo Fisher Scientific) following the manufacturer instructions. A transcription-polymerase chain reaction (RTPCR) One Step using AMV reverse transcriptase (Promega, Brazil) was performed using the specifical primers CPMMV 1280-F (5'-GGC GTT CCA AAA GCT GCC GAT-3') and CPMMV 1696-R (5'-GGA GCC ACC TTT CCA ATC AA-3') (De Marchi et al., 2017). All amplifications consisted of an initial step of $42^{\circ} \mathrm{C}$ for $30 \mathrm{~min}$, a second step of $94^{\circ} \mathrm{C}$ for 2 min, 30 cycles of $94^{\circ} \mathrm{C}$ for $54 \mathrm{sec}$, annealing at $54^{\circ} \mathrm{C}$ for $50 \mathrm{sec}$ and elongation at $72^{\circ} \mathrm{C}$ for $50 \mathrm{sec}$, followed by a final extension step at $72^{\circ} \mathrm{C}$ for $10 \mathrm{~min}$. In order to obtain the complete genome characterisation of the CPMMV isolate from Casa Branca - SP (called CPMMV Casa Branca_BR), the RNA was used for construction of a cDNA library using the Complete ScriptSeq Kit (Epicenter, Illumina) and transcriptome sequencing with Illumina HiSeq2500 platform (Roossinck, Martin \& Roumagnac, 2015) at the Center of Functional Genomics (ESALQ/USP, Piracicaba, Brazil). Adapter sequence removal and quality trimming were performed with CLC Genomics Workbench software version 9.0.3. 
120 The sequence obtained was analysed using the software Geneious v11.1.5. (Kearse et

121 al., 2012) and compared to a dataset composed of 8 CPMMV complete genome isolates

122 from Ghana (Menzel, Winter \& Vetten, 2010), Florida (Rosario et al., 2014) different

123 Brazilian CPMMV isolates described by Zanardo et al., (2014). and a sequence from India

124 retrieved from GenBank. The sequences were compared using MAFFT v7.222 within the

125 Geneious v.11.1.5 software, and phylogenetic analysis was performed using

126 MRBAYERS 3.2.2. (Ronquist \& Huelsenbeck, 2003). Two independent runs were

127 conducted simultaneously using 10 million generations and excluding $25 \%$ from the

128 resulting tree as burnin. Phylogenetic tree was visualized, edited and rooted using

129 FigTree v1.4.4. (tree.bio.ed.ac.uk/software/figtree/). Pairwise comparison between the

130 sequences were performed with the program SDT v.1.2 (Muhire, Varsani \& Martin, 2014)

131 using the MUSCLE alignment option (Edgar, 2004). The CPMMV CP (coat protein) nt

132 sequence obtained in this study were also compared with 33 sequences of CPMMV CP

133 retrieved from GenBank, the phylogenetic analysis of the $\mathrm{CP}$ can be found in

134 Supplementary Figure 1. After virus identification and characterisation, the isolate was

135 maintained in common bean (Phaseolus vulgaris L.) CV. Jalo by whitefly transmission.

136 Virus transmission was performed by transferring whitefly specimens (MEAM1) in cages

137 containing infected soybean leaves for a viral acquisition access period (AAP) of $24 \mathrm{~h}$.

138 Following virus acquisition, whiteflies were transferred to cages containing healthy bean

139 plants at the VC (cotyledon leaves) growth stage, for a 24-h inoculation access period

140 (IAP) under controlled conditions at $30^{\circ} \mathrm{C}$. After inoculation, insecticides (Oberon and

141 Cartap) were sprayed on plants to eliminate all the whitefly adults, nymphs and eggs.

142 Thirty days after the IAP, plants were analysed for the virus presence. After virus 
143 confirmation, the plants were used as source of inoculum for the field inoculation

144 experiments.

\section{Experimental areas}

146 Field experiments were conducted during the $2017 / 2018$ growing season with six cultivars

147 distributed in four different growing areas: cv. BMX POTENCIA RR in Botucatu, State of 148 São Paulo (coordinates: 2248’25.4”S, 48²5’46.4”W, elevation: 739 m, sowing date 149 01/11/2017), cv. M 6410 IPRO and TMG 7062 IPRO in Mogi Mirim, State of São Paulo 150 (coordinates: 22²6'42.8”S 4704'10.8”W, elevation: 687 m, sowing date 15/12/2017) , 151 cv. M 7739 IPRO and M 8372 IPRO in Pedra Preta, State of Mato Grosso (coordinates: 152 1650'30.3”S 5402'39.8”W, elevation: $744 \mathrm{~m}$, sowing date 23/11/2017), and cv. M 9144

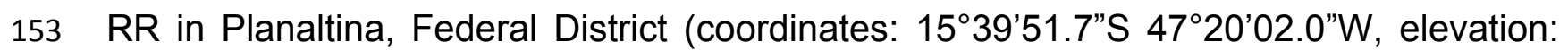
$154887 \mathrm{~m}$, sowing date 27/11/2017). The maximum, minimum and average temperatures 155 and rainfall that occurred during the experimental periods in the four areas were collected 156 from meteorological stations located next to the experimental fields and are available as 157 a climograph in Supplementary Table 2. There is no technical information about 158 susceptibility/resistance to CPMMV available for all tested cultivar.

159 The four sites represented some important soybean producing areas in Brazil. They have 160 contrasting environmental conditions, and the cultivars were selected according to the 161 frequency that they were planted in each region. Parameters such as the occurrence of 162 weeds, diseases, and insect pressure, especially B. tabaci, were monitored throughout 163 the season. Field experiments were approved by the Universidade Estadual Paulista Julio 164 de Mesquita Filho (UNESP) and Fundação de Estudos Agrícolas e Florestais (FEPAF) 165 Processo 1259 Dow 01 Renate Krause-Sakate. 


\section{Experimental design and field inoculation}

167 The experimental design was a randomised block, with two treatments (healthy and 168 infected plants with CPMMV) with five replications. Each plot was comprised of six rows 169 (5m), $0.45 \mathrm{~m}$ between rows and an average of 14 plants per meter (around 200 soybean 170 plants, totalizing around 1,000 plants/treatment).

171 Soybean plants 30 days after sowing were inoculated with CPMMV using as inoculum 172 source leaves of common bean cv Jalo infected with CPMMV. Leaves were ground in 173 phosphate buffer $0.01 \mathrm{M}, \mathrm{pH} 7$ containing the abrasive carborundum (600 mesh). The

174 presence of the virus was detected by RT-PCR using specific primers for CPMMV as 175 described previously.

176 The susceptibility of all cultivar was also tested under the same open field conditions. 177 Approximately 100 seeds per cultivar were sowed in the field in Botucatu during the 178 2019/2020 growing season, and the seedlings were inoculated ten days after emergence. 179 Inoculation and virus detection were performed as described previously.

\section{Field sampling and evaluation of agronomic traits}

A total of 100 soybean samples collected for each treatment were evaluated for CPMMV infection 30 days after inoculation. When the plants were at physiological maturity (R8), the plant height was evaluated by the distance from the soil to the apex of the plant $(\mathrm{cm})$ and the number of pods per plants was obtained by counting the total number of pods per plant. At the harvest, all plants of the plot were hand harvested and run through a thresher. For each plot, the 1,000-grain weight (g) was determined, which was obtained by weighing 1,000 grains from the plants in the plot, and adjusting to $13 \%$ moisture in 
188 addition to grain productivity, which was obtained by weighing the grains produced, and

189 adjusting to $13 \%$ moisture, then converting into $\mathrm{kg} \mathrm{ha}^{-1}$.

\section{CPMMV transmission by soybean seeds}

191 To study the seed-borne capacity of CPMMV, a random sample of seeds were collected 192 from the CPMMV-infected BMX POTENCIA RR plot, harvested in the Botucatu field. 193 These soybean seeds were planted in Styrofoam seedling trays containing Tropstrato HA 194 Hortaliças (Vida Verde Tecnologia em Substratos, Mogi Mirim, SP). The seedling trays were kept in an insect-proof cage. Germination was greater than $90 \%$, and the seedlings did not show any typical disease symptoms. For virus detection, leaf samples were tested using RT-PCR. To compose a sample, leaves of ten plants were collected and combined

in 80 samples tested, totalling 800 plants analysed. Once the presence of CPMMV was detected in a sample, the ten individually plants were tested for the presence of CPMMV. The positive plants were kept in an insect-proof cage for 60 days in order to observe the appearance of symptoms.

\section{Data Analysis}

Because of the interdependency and interrelationship of agronomic traits, principal component analysis (PCA) was performed to investigate the data collected in the current study. PCA was performed using Minitab 17 Statistical Software (2010). Data were also submitted to analysis of variance (ANOVA) using Statview software (Concepts and StatView, 1987) to determine whether significant differences $(p<0.05)$ occurred between treatments. Then means were compared using Tukey's test $(\alpha=5 \%)$. 


\section{RESULTS}

\section{Virus characterisation and phylogenetic analysis}

212 Based on pairwise sequence comparision, the complete genome of the CPMMV isolate

Casa Banca_BR GenBank accession number MT473963) obtained in this study showed

$21499 \%$ of nucleotide identity with the KC774020 - Bean (FL_USA), KC884245 - Soybean

215 (Brazil_MG), KC884244 - Soybean (Brazil_MG) and KC884246 - Soybean (Brazil_MT).

216 According to the classification used by Zanardo et al. (2014), the CPMMV Casa

217 Branca_BR isolate belongs to the BR2 group, which encompasses the most common

218 CPMMV strains found in soybean in Brazil. This isolate was used as inoculum source for

219 virus infection in all field experiments.

The CPMMV phylogenetic tree of the complete nucleotide genome sequence analysis grouped the CPMMV Casa Branca_BR Isolate with five isolates from Brazil and one from The USA (Figure 1). Although there are few CPMMV complete sequences published in GenBank, the analysis showed that the isolate used in this study is representative to the Brazilian isolates.

Virus incidence and symptoms on inoculated plotsln the field assays, where the cultivars were planted according to their regions, the symptoms observed were variable among the cultivars. BMX POTÊNCIA RR, M 7739 IPRO and M 8372 IPRO cultivars were symptomless to CPMMV infection. In contrast, the M 6410 IPRO, TMG 7062 IPRO and M 9144 RR cultivars showed the most severe symptoms. The most common symptoms were chlorosis, mottling and mild symptoms (Figure 2). Due to the variation in symptoms, 
232 the estimate of virus infection was carried out by sampling 100 soybean leaves from the

233 plots followed by molecular analysis. For all the six sap-inoculated soybean cultivars the

234 incidence of CPMMV was greater than $70 \%$ (Table 1). The virus transmission efficiency

235 was $70 \%$ in cv. M 8372 IPRO, 85\% in cv. BMX POTÊNCIA RR, 87\% in cv. M 9144 RR,

$23689 \%$ in cv. M 7739 IPRO, 90\% in cv. TMG 7062 IPRO and 92\% cv. M 6410 IPRO.

237 (INSERT FIGURE 2)

238 Symptoms caused by CPMMV Casa Branca_BR isolate in soybean cultivars were slightly

239 similar under the same field conditions (Figure 3). Symptoms were observed 30 days

240 post-inoculation. BMX POTENCIA RR, M 7739 IPRO and M 8372 IPRO cultivars showed

241 mild mottled symptoms, M 6410 IPRO and TMG 7062 IPRO and the other cultivars

242 showed mottle symptoms and the cultivar M 9144 RR showed weak mosaic.

243 (INSERT FIGURE 3)

244 Field plot experiments and agronomic performance of the cultivars

245 The PCA of soybean cultivars comparing CPMMV-infected and healthy plants showed

246 that the proportion of the variance retained by the first principal component (PC1) was

$24767.5 \%$ and for the second principal component (PC2) corresponded to $22.3 \%$ of the 248 original remaining variance (Figure 4).

249 The exploratory analysis allowed the evaluation of the virus influence on the groups of 250 cultivars and cultivated areas (Figures 4 and 5). Among the cultivars, the cv. M 9144 RR

251 healthy plants had the greatest plant height and were among the varieties that have the

252 highest number of pods per plants, which set this cultivar and treatment apart from the 253 rest. Regarding the 1,000-grain weight, the cultivar that showed the best performance 
254 was TMG 7062 IPRO followed by M 7739 IPRO, M 6410 IPRO and BMX POTÊNCIA

255 IPRO. The greatest productivity was reached by the cultivar BMX POTÊNCIA IPRO,

256 followed by M 7739 IPRO and M 8372 IPRO, being the cv. BMX POTÊNCIA the most

257 affected by the presence of the virus.

258 (INSERT FIGURES 4 AND 5)

259 As expected, each cultivar had distinct performance once they have particular 260 characteristics and they were cultivated in areas with contrasting environmental 261 conditions (Figure 5). The exploration of the data also demonstrated that the cultivars $\mathrm{M}$ 2626410 IPRO and TMG 7062 IPRO cultivated in Mogi Mirim - SP had a close performance 263 to all evaluated traits as well as the cultivars M 7739 IPRO and M 8372 IPRO which were 264 cultivated in Pedra Preta - MT. The cv. M 9144 RR tested in Planaltina - DF showed the 265 most distant performance data comparing to the other cultivars (Figure 6).

\section{6 (INSERT FIGURE 6)}

267 Analysis of variance showed that cultivar tested in this work presented different response 268 to the virus infection, showing a significant $(p<0.05)$ or non-significant reduction in the 269 traits evaluated (Table 1).

270 (INSERT TABLE 1)

271 There was a significant effect $(p<0.05)$ of CPMMV-infection in all agronomic traits

272 evaluated in the cV. BMX POTÊNCIA RR. CPMMV-infected plants have reduction in plant

273 height $(p<0.01, \mathrm{~F}=467.76)$, number of pods per plant $(p<0.01, \mathrm{~F}=36.53)$ and 1,000 -grain

274 weight $(p<0.01, F=11.64)$ that reflected directly in the productivity $(p=0.01, F=11.20)$, 
275 which had a loss of $638 \mathrm{~kg} \mathrm{ha}^{-1}$, this cultivar being the one that had the greater yield loss,

276 approximately $16 \%$.

277 Regarding the cultivar M 6410 IPRO, there was also a significant reduction $(p<0.05)$ in

278 all traits evaluated, and only the plant height $(p=0.74, \mathrm{~F}=0.1)$ did not differ to the cV. TMG

2797062 IPRO. The cultivars tested in Pedra Preta - MT differed significantly only in one 280 parameter each, plant height $(p<0.01, \mathrm{~F}=17.92)$ and number of pods per plant $(p<0.01$,

281 F=8.97), for cv. M 7739 IPRO and M 8372 IPRO, respectively. Although no significant

282 effect of treatment in the yield occurred in both cultivars, there was a reduction of $370 \mathrm{~kg}$

$283 \mathrm{ha}^{-1}$ for cv. M $7739 \operatorname{IPRO}(p=0.07, \mathrm{~F}=4.08)$, and $174 \mathrm{~kg} \mathrm{ha}^{-1}$ for $\mathrm{cv} . \mathrm{M} 8372 \mathrm{IPRO}(p=0.33$, $284 \mathrm{~F}=1.07)$.

285 All traits in the cv. M 9144 RR, except for plant height, were affected significantly $(p<0.05)$ 286 due to CPMMV-infection. Although the height was significantly the same for the 287 treatments $(p=0.51, F=0.47)$, the reduction caused in number of pods per plant $(p=0.25$, $288 \mathrm{~F}=7.57)$ and 1000-grain weight $(p<0.01, F=182328.14)$ in the diseased plants directly 289 affected the in productivity $(p=0.01, \mathrm{~F}=9.85)$ with a reduction of $316 \mathrm{~kg} \mathrm{ha}^{-1}$, or 290 approximately $14 \%$.

291 CPMMV transmission by soybean seeds

292 From 800 seedlings obtained from seeds harvested in the cv. BMX POTÊNCIA RR 293 CPMMV-infected field plot, three plants were found to be infected by CPMMV, confirmed 294 by RT-PCR. Not a single plant developed typical disease symptoms after emergence until 295 their senescence. The observed percentage of plants infected with the virus was $0.375 \%$, 
296 but it is important to mention that the incidence of the virus in these plots was around $85 \%$

297 and seeds from healthy soybean plants were part of the sample.

\section{DISCUSSION}

300

301

302

303

304

305

306

307

308

309

310

311

312

313

314

315

316

317

The data obtained in this study revealed that CPMMV causes reduction of productivity, plant height, 1000-grain weight and pods per plant in the main soybean cultivars used in Brazil, suggesting that this virus may be responsible for economic losses for soybean crop in our country. Additionally, the CPMMV-seed transmission data for a Brazilian isolate highlights the seed importance as a primary inoculum source in the field, especially in areas with low whitefly population, such as the southern states of the country.

CPMMV was first recorded in Brazil in common bean in the 1980s (Costa et al.,1983), and reported as a threat to soybean production in 2002 (Almeida et al., 2003). The losses reported at that time were higher than $85 \%$, since the cultivars used developed the stem necrosis symptom that affected the whole plant (Almeida et al., 2003). The new cultivars has reduced the impact of this disease in soybean since there is no longer the development of systemic necrosis but infected plants show symptoms of mottling and mosaic (Arias et al., 2015). Although some soybean cultivars are symptomless when infected by CPMMV, our results provide evidence that the productivity can be affected. In our study, the highest reduction in productivity was observed for cv. BMX POTENCIA RR (638 kg ha-1), a cultivar that did not show any visual symptoms of CPMMV infection (Table 1, Figure 3). The soybean genotype M 9144 RR, also asymptomatic for CPMMV infection, showed a reduction in productivity around $316 \mathrm{~kg} \mathrm{ha}^{-1}$ (Table 1). It is also 
318 important to highlight that even a reduction in productivity of $174 \mathrm{~kg} \mathrm{ha}^{-1}$ observed for $\mathrm{cv}$.

319 M 8372 IPRO (asymptomatic for CPMMV infection) may cause an economic impact

320 considering that an infected soybean field can show a reduction of productivity around 3

321 bags ha-1 $^{-1}$, the bag (60 kg) price is, on average, 20.00 US\$ (CEPEA, 2019). As Brazil is

322 the largest soybean oilseed exporter in the world (USDA. 2019), the amount of bags

323 reduction impacts directly not only for the farmers, but also the Brazilian economy.

324 The seed-borne virus transmission can also be an important component of the

325 epidemiology of the disease in the field. It has already been reported that different isolates

326 of CPMMV can be seed transmitted, as observed for cowpea, soybean and common bean

327 seeds in Ghana (Brunt \& Kenten, 1973) and yardlong bean seeds in Venezuela (Brito et

328 al., 2012). In Thailand, the virus was observed to be transmitted by soybean seeds at a

329 frequency lower than 1\% (Iwaki et al., 1982) but in India, the seed-borne nature of the

330 virus was detected in several soybean cultivars with higher rates of transmission, ranging

331 from $0.62 \%$ to $14.2 \%$ (Yadav et al., 2013). Here we provide evidence that Brazilian

332 CPMMV soybean isolates can be seed transmitted. In the world scale, phylogenetic

333 analysis of the CP amino acids sequences demonstrate that CPMMV isolate from Casa

334 Branca clusters together with CPMMV isolate from Argentina (KP402890) and Florida

335 (KC774020), indicating a common origin (Zanardo \& Carvalho, 2017). Our data reinforce

336 that the CPMMV capacity to be transmitted by seeds might have contribute for virus

337 dissemination through different countries, highlighting the importance of studying the

338 transmission capacity of this virus by infected seeds.

339 In addition, a few infected seeds can provide enough CPMMV inoculum to be

340 disseminated by the efficient vector $B$. tabaci that is considered one of the main important 
341 pest for soybean, common bean, melon and tomatoes in Brazil (Brasil, 2018) and a

342 excelent vector of begomovirus, carlavirus and crinivirus (Navas-Castillo et al., 2011;

343 Gilbertson et al., 2015). Bemisia tabaci MEAM1 (biotype B) is the predominant species in

344 soybean in our country (Moraes et al., 2018) and is a highly polyphagous insect that can

345 feed on more than 600 species of plants (Polston, De Barro \& Boykin, 2014). The Brazilian

346 middle-western region is the largest soybean and common bean producer, and both crops

347 are cultivated near to each other. It is already known that whiteflies can colonize soybean

348 and common bean, as well the CPMMV can infect both crops (Marubayashi, Yuki \&

349 Wutke, 2010; Inoue-Nagata et al., 2016). The combination of these conditions may

350 contribute for CPMMV transmission, since the common beans can serve as inoculum

351 source of whiteflies and CPMMV to the soybean crop and vice versa.

352 In summary, we conclude that even asymptomatic for some important soybean genotypes

353 currently planted in Brazil, the CPMMV infection can affect the soybean yield. Seed

354 transmission of the virus can also be an important component for CPMMV dissemination

355 in the field. Soybean breeding programs need to take into account CPMMV infection in 356 order to provide genotypes that are resistant/tolerant to the virus.

\section{REFERENCES}

Almeida AMR. 2008. Viroses da soja no Brasil: sintomas, etiologia e controle. Serie Documentos 306:1-62.

Almeida AMR, Piuga FF, Kitajima EW, Gaspar JO, Valentin N, Benato LC, Marin SRR, Binneck E, de OLIVEIRA TG, BELINTANI P. 2003. Necrose da haste da soja. Serie Documentos 221:1-48.

Almeida AMR, Piuga FF, Marin SRR, Kitajima EW, Gaspar JO, Oliveira TG de, Moraes TG de. 2005. Detection and partial characterization of a carlavirus causing stem 
365

366

367

368

369

370

371

372

373

374

375

376

377

378

379

380

381

382

383

384

385

386

387

388

389

390

391

necrosis of soybean in Brazil. Fitopatologia Brasileira 30:191-194. DOI: 10.1590/S0100-41582005000200016.

Arias CAA, Almeida AMR, Mituti T, Kitajima EW. 2015. Inheritance of tolerance to Cowpea Mild Mottle Virus in soybean. Crop Breeding and Applied Biotechnology 15:132-138. DOI: 10.1590/1984-70332015v15n3a24.

De Barro PJ, Liu S-S, Boykin LM, Dinsdale AB. 2011. Bemisia tabaci : A Statement of Species Status. Annual Review of Entomology 56:1-19. DOI: 10.1146/annurevento-112408-085504.

Brace RC, Fehr WR, Graham MA. 2012. Inheritance and molecular mapping of an allele providing resistance to a Cowpea mild mottle-like virus in soybean. Crop Science 52:2109-2114. DOI: 10.2135/cropsci2012.01.0042.

Brasil. 2018. Portaria N 112, de 8 de Outubro de 2018. Brasilia.

Brasil. 2019. Instrução Normativa N¹6, de 4 de Junho de 2019. Brasilia.

Brito M, Fernández-Rodríguez T, Garrido MJ, Mejías A, Romano M, Marys E. 2012. First report of cowpea mild mottle carlavirus on yardlong bean (vigna unguiculata subsp. sesquipedalis) in venezuela. Viruses 4:3804-3811. DOI: 10.3390/v4123804.

Brunt AA, Kenten RH. 1973. Cowpea mild mottle, a newly recognized virus infecting cowpeas (Vigna unguiculata) in Ghana. Annals of Applied Biology 74:67-74. DOI: 10.1111/j.1744-7348.1973.tb07723.x.

Celli MG, Perotto MC, Merino MC, Nome CFD, Flores CR, Conci VC. 2016. First report of Cowpea mild mottle virus in chia ( Salvia hispanica ). Crop Protection 89:1-5. DOI: 10.1016/j.cropro.2016.05.014.

CEPEA. 2019. Available at www.cepea.esalq.usp.br (acessado 21 de janeiro de 2019).

Cheruku D, Lal SK, Talukdar A, Mandal B. 2017. Inheritance and mapping of resistance against Cowpea mild mottle virus strain D1 in soybean. Plant Breeding 136:155160. DOI: $10.1111 / \mathrm{pbr} .12455$.

Conab. 2018. Acompanhamento da safra brasileira: grãos, décimo segundo 
392 393

394

395

396

397

398

399

400

401

402

403

404

405

406

407

408

409

410

411

412

413

414

415

416

417

418

419

levantamento, setembro 2018. Companhia Nacional de Abastecimento, Brasília:1148.

Concepts and StatView. 1987. StatView II. Berkeley, CA: Abacus Concepts Inc.

Costa, AS; Gaspar, JO; Vega J. 1983. Mosaico angular do feijão jalo causado por um carlavírus transmitido pela mosca branca Bemisia tabaci. Fitopatologia Brasileira 8:325-327.

Fonseca Barbosa L, Yuki VA, Marubayashi JM, De Marchi BR, Perini FL, Pavan MA, de Barros DR, Ghanim M, Moriones E, Navas-Castillo J, Krause-Sakate R. 2015. First report of Bemisia tabaci Mediterranean ( $Q$ biotype) species in Brazil. Pest Management Science 71:501-504. DOI: 10.1002/ps.3909.

Gilbertson RL, Batuman O, Webster CG, Adkins S. 2015. Role of the Insect Supervectors Bemisia tabaci and Frankliniella occidentalis in the Emergence and Global Spread of Plant Viruses. Annual Review of Virology 2:67-93. DOI: 10.1146/annurev-virology-031413-085410.

Hirakuri M, Lazzarotto J. 2014. O agronegócio da soja nos contextos mundial e brasileiro. Serie Documentos 349:1-70.

Horowitz AR, Ishaaya I. 2014. Dynamics of biotypes B and Q of the whitefly Bemisia tabaci and its impact on insecticide resistance. Pest ma 2014:1568-1572. DOI: 10.1002/ps.3752.

Inoue-Nagata AK, Carvalho CM, Zerbini FM, Rezende JAM, Krause-Sakate R, Nagata T. 2016. Vírus Transmitidos por Mosca-Branca no Brasil: Vetores, Principais doenças e Manejo. RAPP 24:7-29.

Kearse M, Moir R, Wilson A, Stones-havas S, Sturrock S, Buxton S, Cooper A, Markowitz S, Duran C, Thierer T, Ashton B, Meintjes P, Drummond A. 2012. Geneious Basic: An integrated and extendable desktop software platform for the organization and analysis of sequence data. Bioinformatics Applications Note 28:1647-1649. DOI: 10.1093/bioinformatics/bts199.

King A, Adams M, Carstens E, Lefkowitz E. 2011. Virus taxonomy: ninth report of the 
International Committee on Taxonomy of Viruses. Elsevier-Academic Press.

421

422

Lapidot M, Legg JP, Wintermantel WM, Polston JE. 2014. Management of WhiteflyTransmitted Viruses in Open-Field Production Systems. In: Control of Plant Virus Diseases. Elsevier Inc., 147-206. DOI: 10.1016/B978-0-12-801246-8.00003-2.

Lourenção. AL; Yuki, VA; Alves S. 1999. Epizootia de Aschersonia cf . goldiana em Bemisia tabaci ( Homoptera : Aleyrodidae ) Biótipo B no Estado de São Paulo. An Soc Entomol Brasil 28:343-345.

De Marchi BR, Bello VH, Watanabe LFM, Silva FB da, Müller C, Pavan MA, Krausesakate R. 2018. Characterization and complete genome sequence of groundnut ringspot orthotospovirus in soybean in Brazil. Journal of Plant Pathology:42161. DOI: 10.1007/s42161-018-0172-1.

De Marchi BR, Marubayashi JM, Favara GM, Yuki VA, Watanabe LFM, Barbosa LF, Pavan MA, Krause-Sakate R. 2017. Comparative transmission of five viruses by Bemisia tabaci NW2 and MEAM1. Tropical Plant Pathology 42:495-499. DOI: 10.1007/s40858-017-0186-9.

Marubayashi JM, Yuki VA, Wutke EB. 2010. Transmissão do Cowpea mild mottle virus pela mosca branca Bemisia tabaci biótipo B para plantas de feijão e soja. Summa Phytopathologica 36:158-160.

Menzel W, Winter S, Vetten HJ. 2010. Complete nucleotide sequence of the type isolate of Cowpea mild mottle virus from Ghana. Archives of Virology 155:2069-2073. DOI: 10.1007/s00705-010-0821-y.

Moraes LA, Muller C, Freitas Bueno RCO, Santos A, Bello VH, De Marchi BR, Watanabe LFM, Marubayashi JM, Santos BR, Yuki VA. 2018. Distribution and phylogenetics of whiteflies and their endosymbiont relationships after the Mediterranean species invasion in Brazil. Scientific reports 8:14589.

Navas-Castillo J, Fiallo-Olivé E, Sánchez-Campos S. 2011. Emerging Virus Diseases Transmitted by Whiteflies. Annual Review of Phytopathology 49:219-248. DOI: 10.1146/annurev-phyto-072910-095235. 
448 De Oliveira MAR, Carpentieri-Pípolo V, Nora TD, Vieira ESN, Prete CEC, Schuster I. 449 2018. RBC2, a new dominant gene for resistance of soybean to cowpea mild mottle 450 virus: Inheritance and mapping. Crop Breeding and Applied Biotechnology 18:169175. DOI: 10.1590/1984-70332018v18n2a24.

452

453

454

455

456

457

458

459

460

461

462

463

464

465

466

467

468

469

470

471

472

473

474

475

Polston JE, De Barro P, Boykin LM. 2014. Transmission specificities of plant viruses with the newly identified species of the Bemisia tabaci species complex. Pest Management Science 70:1547-1552. DOI: 10.1002/ps.3738.

Ronquist F, Huelsenbeck JP. 2003. MrBayes 3: Bayesian phylogenetic inference under mixed models. Bioinformatics 19:1572-1574. DOI: 10.1093/bioinformatics/btg180.

Roossinck MJ, Martin DP, Roumagnac P. 2015. Plant virus metagenomics: Advances in virus discovery. Phytopathology 105:716-727. DOI: 10.1094/PHYTO-12-14-0356RVW.

Rosario K, Capobianco H, Ng TFF, Breitbart M, Polston JE. 2014. RNA viral metagenome of whiteflies leads to the discovery and characterization of a whiteflytransmitted Carlavirus in North America. PLOS ONE 9. DOI: 10.1371/journal.pone.0086748.

Suryanto A, Kuswanto K, Sitompul S, Kasno A. 2014. Estimation Of Number And Genes Actions Of Cpmmv (Cowpea Mild Mottle Virus) Disease Resistance Genes On Soybean Crop. IOSR Journal of Agriculture and Veterinary Science 7:51-56. DOI: $10.9790 / 2380-07535156$.

Tamai, MA; Martins, MC; Lopes P. 2006. Perda de produtividade em cultivares de soja causada pela mosca-branca no cerrado baiano. Comunicado Técnico 21, Fundação $B A: 7 p$.

USDA. 2019. Oilseeds: World Markets and Trade. Available at https://apps.fas.usda.gov/psdonline/circulars/oilseeds.pdf

Yadav MK, Biswas KK, Lal SK, Baranwal VK, Jain RK. 2013. A Distinct Strain of Cowpea mild mottle virus Infecting Soybean in India. Journal of Phytopathology 161:739-744. DOI: 10.1111/jph.12119. 
476 Zanardo LG, Carvalho CM. 2017. Cowpea mild mottle virus (Carlavirus,

477 Betaflexiviridae): a review. Tropical Plant Pathology 42:417-430. DOI:

$478 \quad 10.1007 /$ s40858-017-0168-y.

479 Zanardo LG, Silva FN, Bicalho AAC, Urquiza GPC, Lima ATM, Almeida AMR, Zerbini

480 FM, Carvalho CM. 2014a. Molecular and biological characterization of Cowpea mild 481 mottle virus isolates infecting soybean in Brazil and evidence of recombination. 482 :456-465. DOI: 10.1111/ppa.12092.

483 484

485

486

487

Zanardo L, Silva F, Lima A, Milanesi D, Castilho-Urquiza G, Almeida A, Zerbini F, 488 Carvalho C. 2014c. Molecular variability of cowpea mild mottle virus infecting soybean in Brazil. Archives of Virology 159:727-737. DOI: 10.1007/s00705-013-

490 1879-0.

491 
Figure 1

CPMMV SDT and phylogenetic tree legenda

(a) Pairwise identity analysis and phylogenetic analysis. Genome pairwise identity based on complete sequence of different CPMMV isolates available in GenBank using SDT v1.2. (b)

Phylogenetic tree based on the complete sequence of different CPMMV isolates available in GenBank using Bayesian inference (implemented in MRBAYES V. 3.1, with model GTR+I+G and 10 million generations). Cucumber vein-clearing virus (CuVCV; genus Carlavirus, family Betaflexiviridae) was used as outgroup.

(a)

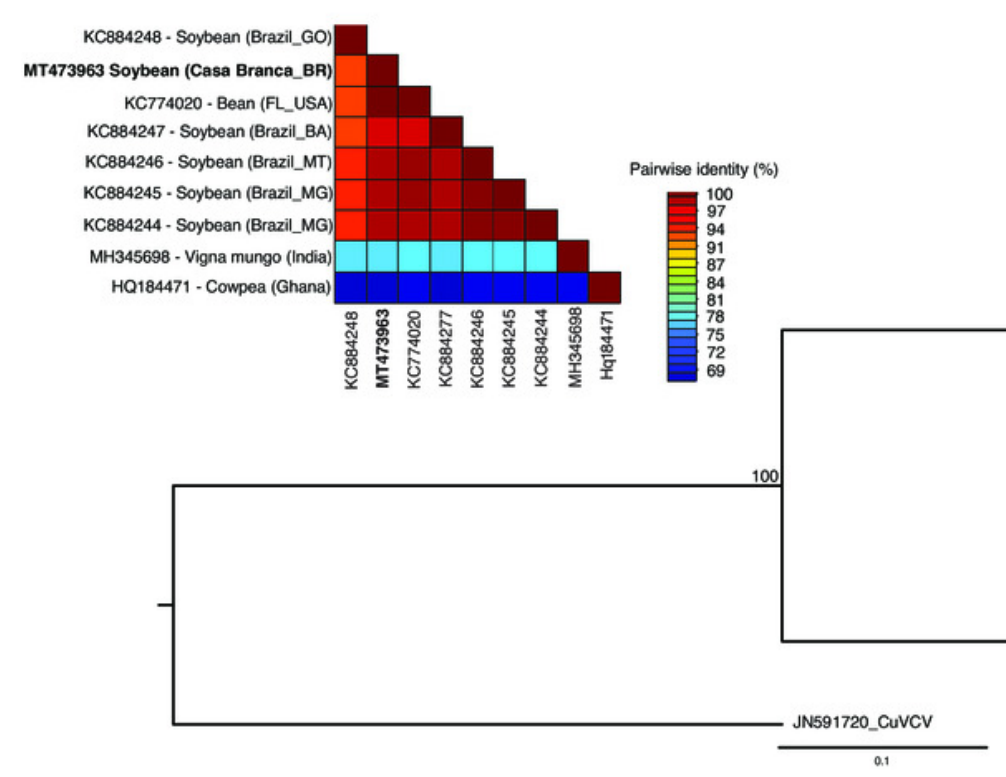

(b)

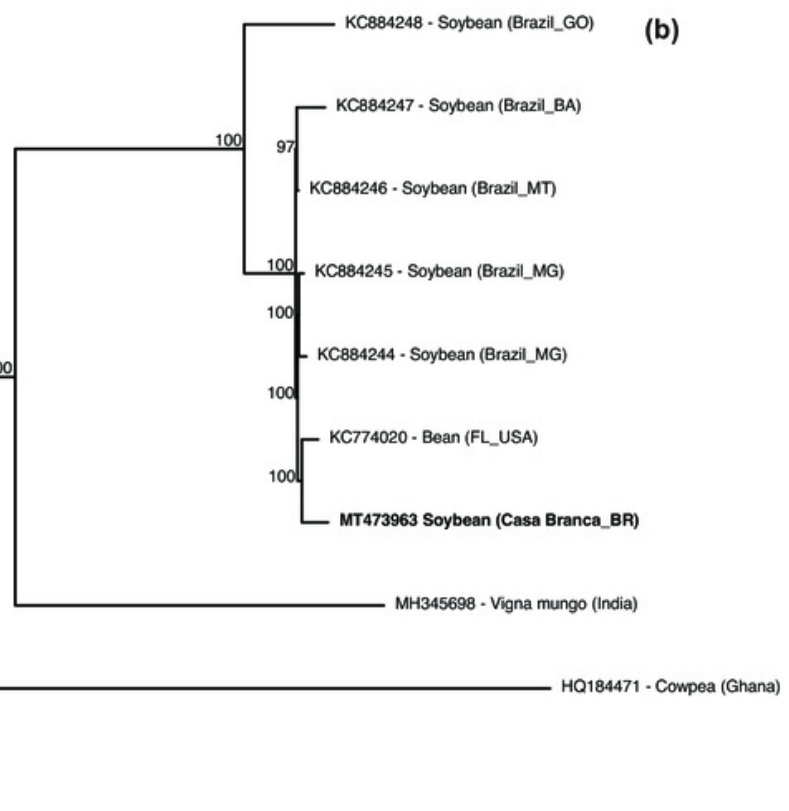




\section{Figure 2}

Symptoms observed.

Symptoms observed in the six cultivars tested in the field experiment: (a) BMX POTÊNCIA RR,

(d) M 7739 IPRO and (e) M 8372 IPRO showed to be symptomless; (c) M 7062 IPRO, (b) M 6410 IPRO and (f) M 9144 RR showed chlorosis, mild and mottling symptoms.
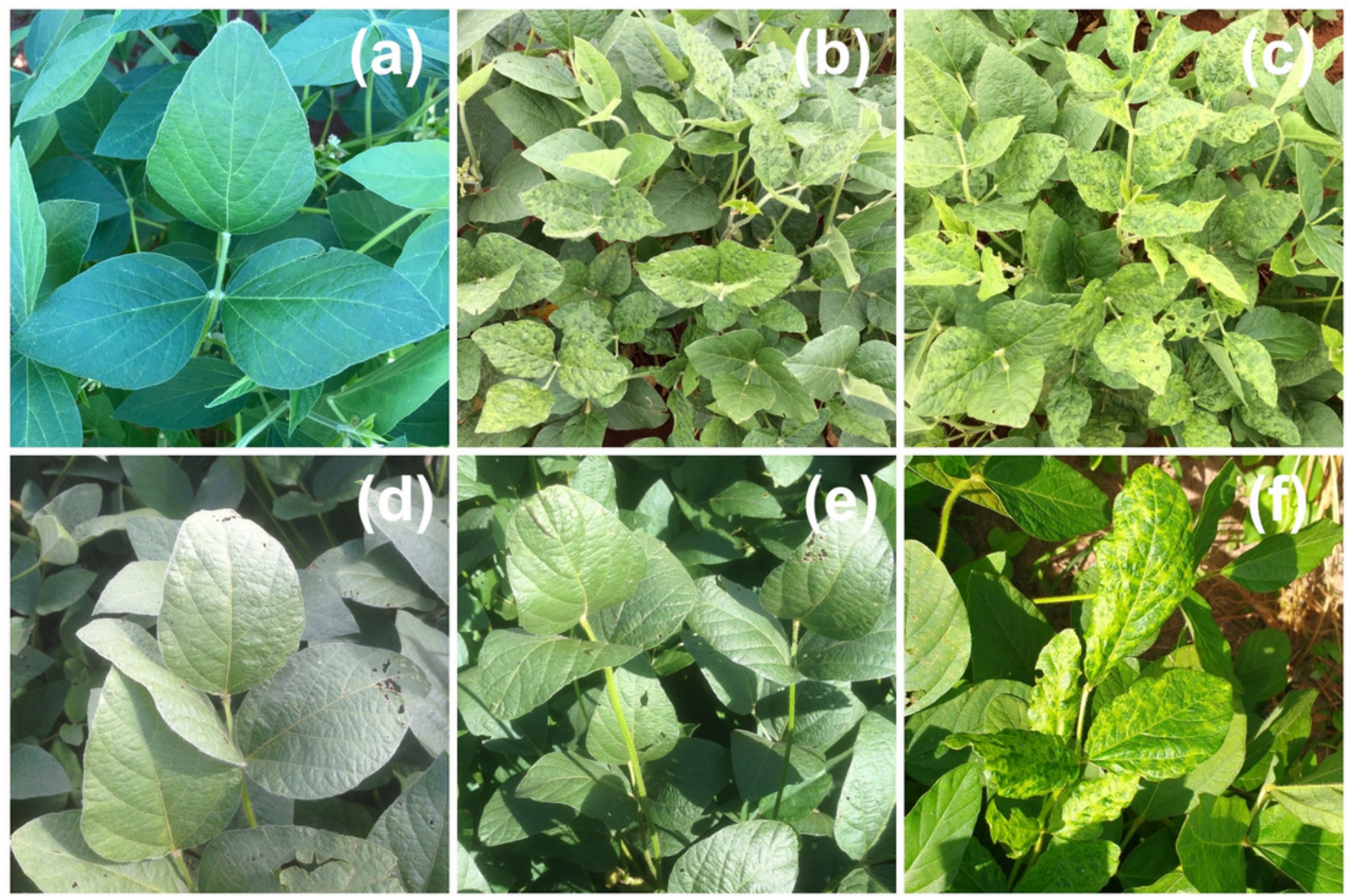


\section{Figure 3}

\section{Same condition assay}

Susceptibility of cultivar under the same open field conditions in Botucatu - SP. (a) BMX POTÊNCIA RR, (d) M 7739 IPRO and (e) M 8372 IPRO showed mild mottle symptoms; (b) M 6410 IPRO and (c) M 7062 IPRO showed mottle symptoms and (f) M 9144 RR showed weak mosaic.
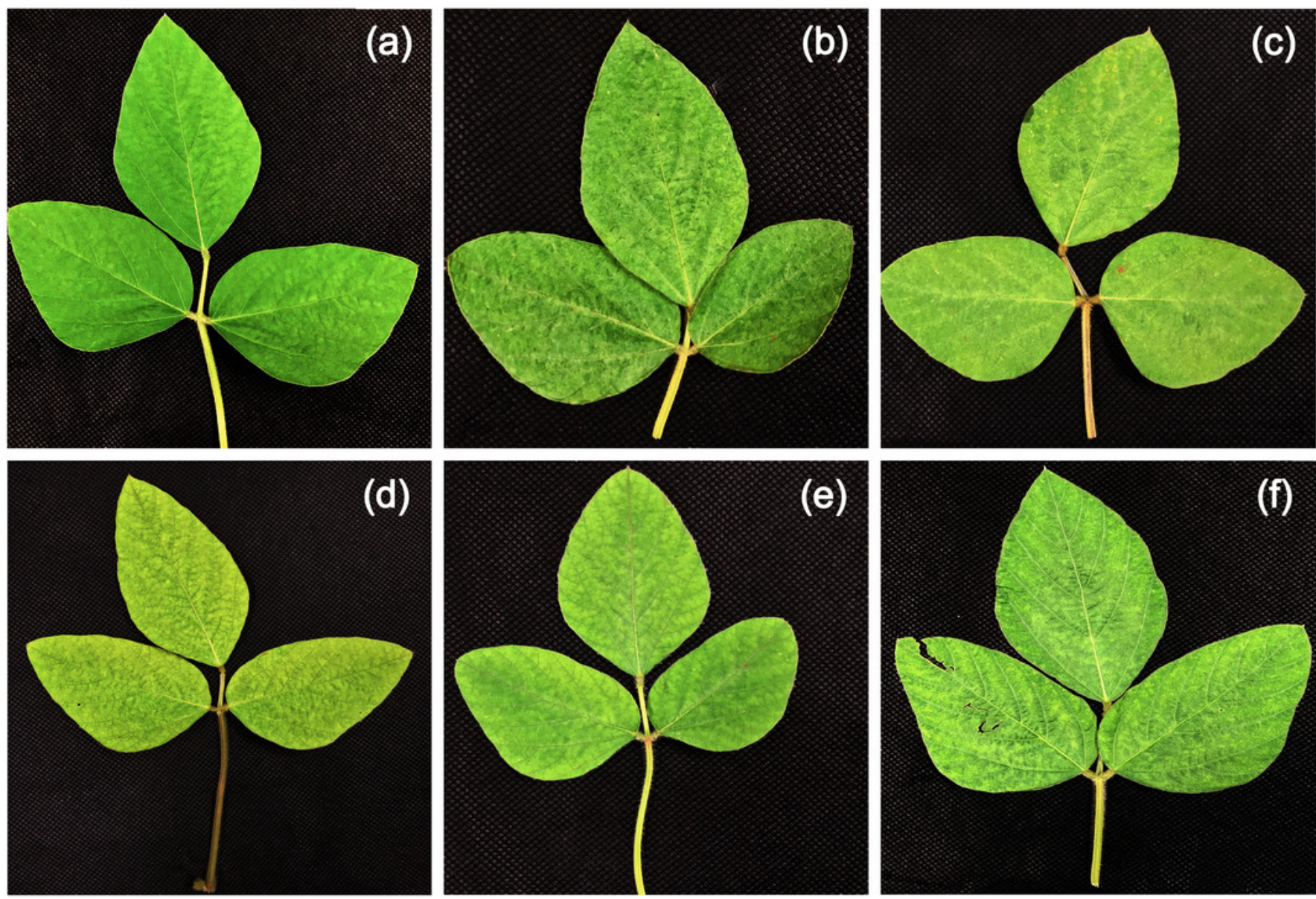
Figure 4

Principal component analysis (PCA) of the agronomic traits

Projection of vectors of traits: plant height in cm, number of pods per plants, 1000-grain weight in $\mathrm{g}$ and productivity in $\mathrm{kg} \mathrm{ha}{ }^{-1}$.

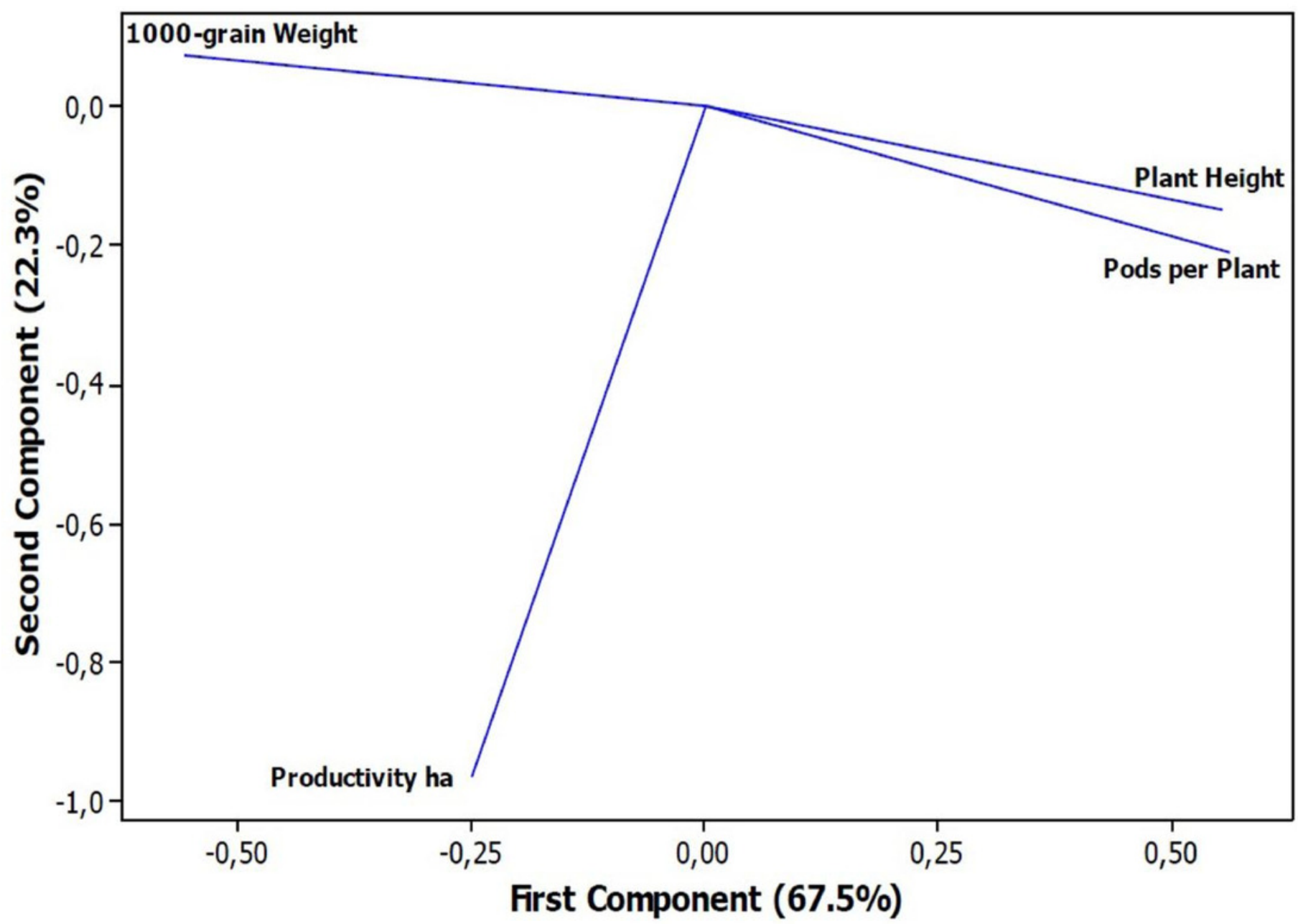


Figure 5

Principal component analysis (PCA) of the agronomic traits

Biplot graph with dispersion of six soybean cultivars according to the principal components (PC1 and PC2). BMX POTÊNCIA RR healthy plants, O BMX POTÊNCIA RR CPMMV-Infected plants, $\square$ M 6410 IPRO healthy plants, $\square$ M 6410 IPRO CPMMV-Infected plants, $\bullet 7062$ IPRO healthy plants, $\triangle$ TMG 7062 IPRO CPMMV-Infected plants, $\Delta$ M 7739 IPRO healthy plants, ^ M 7739 IPRO CPMMV-infected plants, — M 8372 IPRO healthy plants, > M 8372 IPRO CPMMV-infected plants, 4 M 9144 RR healthy plants, < M 9144 RR CPMMV-infected plants.

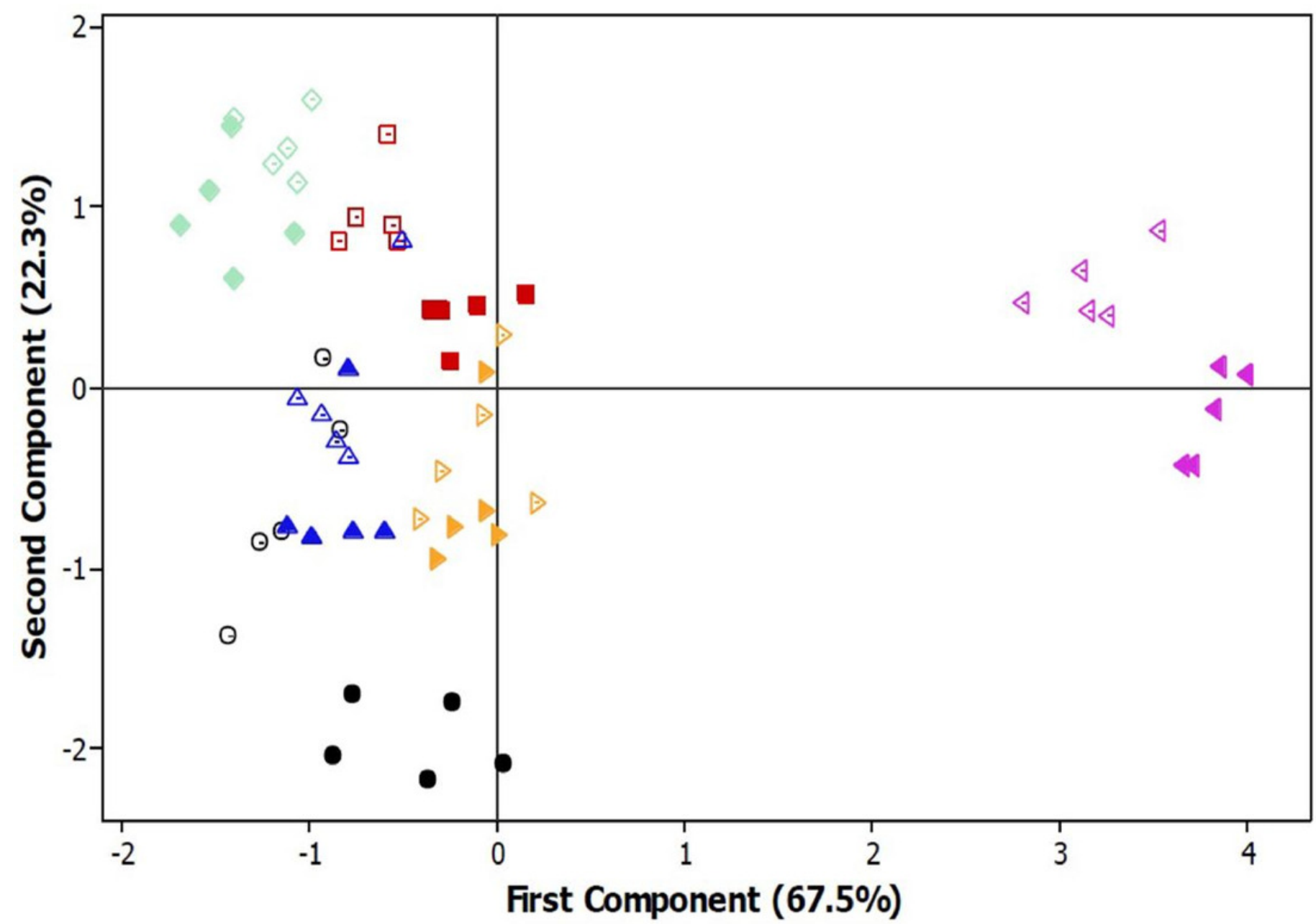


Figure 6

Principal component analysis (PCA) of the agronomic traits

Biplot graph with dispersion of four areas according to the principal components (PC1 and PC2). Botucatu, São Paulo, @ Mogi Mirim, São Paulo, • Pedra Preta, Mato Grosso \ Planaltina, Federal District.

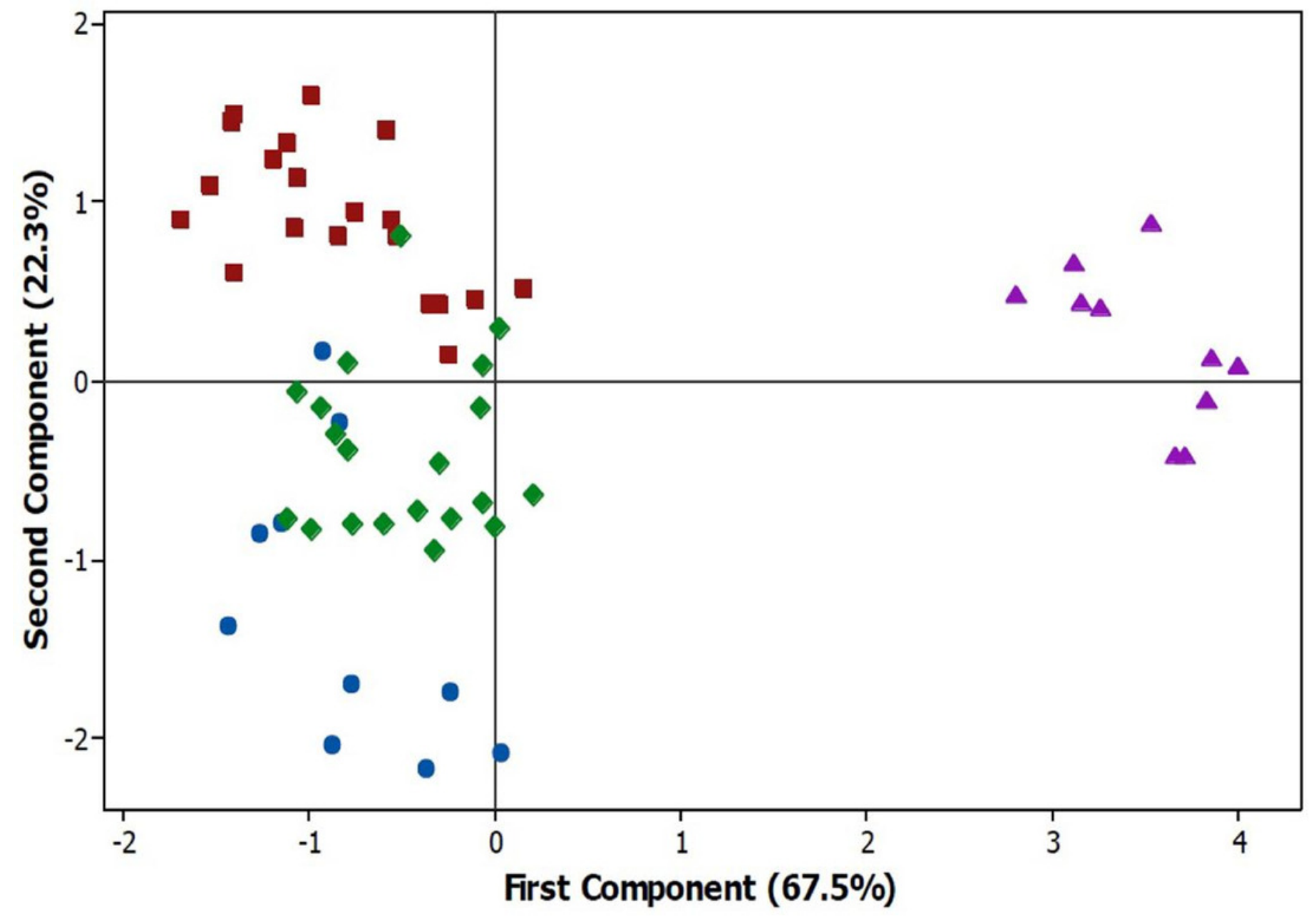




\section{Table $\mathbf{1}$ (on next page)}

Percentage of infeceted plant ande mean of agronomic traits of fields assays according their cultivar

Mean followed by the same letter within rows indicate no significant $(p<0.05)$ difference between healthy and CPMMV-infected plants according to an ANOVA. 


\begin{tabular}{|c|c|c|c|c|c|c|c|c|c|c|c|}
\hline \multirow{2}{*}{ Location } & \multirow{2}{*}{ Cultivar } & \multirow{2}{*}{$\begin{array}{l}\text { Infected } \\
\text { Plants } \\
(\%)\end{array}$} & \multicolumn{2}{|c|}{ Plant Height (cm) } & \multicolumn{2}{|c|}{ Pods per plant } & \multicolumn{2}{|c|}{$\begin{array}{c}1,000 \text {-grain weight } \\
(\mathrm{g})\end{array}$} & \multicolumn{2}{|c|}{ Yield $\left(\mathrm{kg} \mathrm{ha}^{-1}\right)$} & \multirow{2}{*}{$\begin{array}{c}\text { Yield } \\
\text { loss }(\mathrm{kg} \\
\left.\mathrm{ha}^{-1}\right)\end{array}$} \\
\hline & & & $\begin{array}{c}\text { Health } \\
y\end{array}$ & $\begin{array}{l}\text { CPMMV } \\
\text {-infected }\end{array}$ & Healthy & $\begin{array}{l}\text { CPMMV } \\
\text {-infected }\end{array}$ & Healthy & $\begin{array}{l}\text { CPMMV } \\
\text {-infected }\end{array}$ & $\begin{array}{c}\text { Health } \\
y\end{array}$ & $\begin{array}{r}\text { CPMMV } \\
\text {-infected }\end{array}$ & \\
\hline Botucatu & $\begin{array}{c}\text { BMX } \\
\text { POTENCIA } \\
\text { RR }\end{array}$ & 85 & $78.80 a$ & $60.60 b$ & $82.10 a$ & $40.30 \mathrm{~b}$ & $\begin{array}{c}149.60 \\
a\end{array}$ & $132.60 \mathrm{~b}$ & $4,029 a$ & $3,391 b$ & 638 \\
\hline \multirow[t]{2}{*}{$\begin{array}{l}\text { Mogi } \\
\text { Mirim }\end{array}$} & $\begin{array}{l}\text { M } 6410 \\
\text { IPRO }\end{array}$ & 92 & $68.71 \mathrm{a}$ & $59.71 b$ & $70.15 a$ & $41.26 \mathrm{~b}$ & $\begin{array}{c}139.37 \\
a \\
\end{array}$ & $129.13 b$ & $2,564 a$ & $2,330 b$ & 234 \\
\hline & $\begin{array}{c}\text { TMG } 7062 \\
\text { IPRO }\end{array}$ & 90 & $67.13 a$ & $66.86 a$ & $34.22 \mathrm{a}$ & $30.92 b$ & $\begin{array}{c}186.05 \\
a\end{array}$ & $169.01 b$ & $2,393 a$ & $2,145 b$ & 248 \\
\hline \multirow[t]{2}{*}{$\begin{array}{l}\text { Pedra } \\
\text { Preta }\end{array}$} & $\begin{array}{l}\text { M } 7739 \\
\text { IPRO }\end{array}$ & 89 & $74.76 a$ & $70.84 b$ & $45.68 a$ & $42.89 a$ & $\begin{array}{c}145.54 \\
a\end{array}$ & $144.97 a$ & $3,323 a$ & $2,953 a$ & 370 \\
\hline & $\begin{array}{l}\text { M } 8372 \\
\text { IPRO }\end{array}$ & 70 & $86.84 a$ & $84.48 a$ & $50.82 a$ & $44.40 \mathrm{~b}$ & $\begin{array}{c}123.66 \\
a\end{array}$ & $119.00 a$ & $3,230 a$ & $3,056 a$ & 174 \\
\hline Planaltina & M 9144 RR & 87 & $\begin{array}{c}123.13 \\
a\end{array}$ & $121.07 a$ & $61.60 a$ & $42.45 b$ & $\begin{array}{c}148.71 \\
a\end{array}$ & $105.45 b$ & $2,278 a$ & $1,962 b$ & 490 \\
\hline
\end{tabular}

